Review

\title{
Recombinant Cytokines from Plants
}

\author{
Agnieszka Sirko $^{1}{ }^{1 *}$, Tomas Vaněk ${ }^{2}$, Anna Góra-Sochacka ${ }^{1}$ and Patrycja Redkiewicz ${ }^{1}$ \\ 1 Institute of Biochemistry and Biophysics Polish Academy of Sciences, ul. Pawinskiego 5a, \\ 02-106 Warsaw, Poland; E-Mails: annag@ibb.waw.pl (A.G.-S.); PatiRed@ibb.waw.pl (P.R.) \\ 2 Laboratory of Plant Biotechnologies, Joint Laboratory of Institute of Experimental Botany and \\ Institute of Crop Research, Prague, Czech Republic; E-Mail: vanek@ueb.cas.cz \\ * Author to whom correspondence should be addressed; E-Mail: asirko@ @ibb.waw.pl; \\ Tel.: +48-22-658-4801; Fax: +48-22-658-4804.
}

Received: 31 March 2011; in revised form: 11 May 2011 / Accepted: 27 May 2011 /

Published: 3 June 2011

\begin{abstract}
Plant-based platforms have been successfully applied for the last two decades for the efficient production of pharmaceutical proteins. The number of commercialized products biomanufactured in plants is, however, rather discouraging. Cytokines are small glycosylated polypeptides used in the treatment of cancer, immune disorders and various other related diseases. Because the clinical use of cytokines is limited by high production costs they are good candidates for plant-made pharmaceuticals. Several research groups explored the possibilities of cost-effective production of animal cytokines in plant systems. This review summarizes recent advances in this field.
\end{abstract}

Keywords: cytokines; pharmaceutical proteins; plant-based production systems; molecular farming; interleukins; transgenic plants

\section{Introduction}

Development of DNA recombination and plant transformation techniques resulted in creating the novel protein production platforms based on either whole plants or plant cells. The results of the first experiments describing the plant-based production of pharmaceutical proteins were published about 25 years ago. The successful production of the human growth hormone in tobacco and sunflower [1] and of albumin in tobacco and potato [2] indicated that plant-based production systems might be used for the production of mammalian proteins. The process of using plant-based systems as highly 
effective production platforms for the molecules with biotechnological (industrial or pharmaceutical) significance is named molecular farming, while the pharmaceutical products obtained in the plant-based systems are often called plant-made pharmaceuticals (PMPs). At present, a list of PMPs in various stages of development or potential commercialization is quite extensive and includes various antibodies and their fragments, vaccine antigens, blood substitutes, enzymes, cytokines and other important and valuable proteins. Multiple examples of such proteins and the extensive evaluation of the advantages and disadvantages of various plant-based platforms for the expression of the particular targets can be found in many recent reviews (for example, [3], see also below), therefore this work is limited only to a small group of PMPs, the cytokines.

\section{Cytokines and Their Therapeutic Application}

Cytokines are small polypeptides, proteins or glycoproteins involved in the regulation of processes as diverse as proliferation, differentiation and mobility of cells. Cytokines are important components of the immune system; however they also participate in embryogenesis, affect the hematopoietic system and act on neuronal cells. The anatomic and structural distinctions between hormones and cytokines are unclear and cytokines are sometimes named the hormones of immune system. They can have an affect not only on cells in the close proximity but also those in distant organs. Cytokines are characterized by a considerable complexity of actions such as redundancy, pleiotropy, multifunctionality, synergistic or antagonistic effects and cascades of positive or negative feedbacks. At present, more than 100 different cytokines are known. Several methods of division of this large family into subgroups have been used. The most convenient seems to be functional categorization according to KEGG (Koto Encyclopedia of Genes and Genomes [4]). As shown in Figure 1, at least 8 families can be distinguished: Class I cytokines (hematopoietin family), Class II cytokines (interferons/IL-10 family), platelet-derived growth factors (PDGF), tumor necrosis factors (TNF family), IL-1 family, IL-17 family, tumor growth factor family (TGF-beta family) and chemokines. For more information about the cytokines the reader is referred to the Cytokines \& Cells Online Pathfinder Encyclopedia (COPE) [5].

An imbalance in cytokine production or signaling contributes to various pathological immune and inflammatory disorders. In addition, plasma levels of various cytokines may give information on the presence, or even predictive value of inflammatory processes involved in autoimmune diseases such as rheumatoid arthritis. The biological role of cytokines and their dual (immunosuppressive as well as immunostimulatory) properties are a strong indication for multiple clinical applications. A number of recombinant cytokines have been approved for clinical use (Table 1) and multiple cytokine therapies are in clinical trials [6-8]. Not only the cytokines but also cytokine receptors, antagonists of the cytokine receptors and the relevant specific antibodies can be used in therapy [8]. Significant numbers of cytokines have been tested as potential adjuvants of immunological response, particularly during mucosal immunizations, such as oral, intranasal and intravaginal [2,9]. Granulocyte-macrophage colony stimulating factor (GM-CSF) seems to e one of the best candidates for PMP because it is relatively stable, consists of one kind of polypeptide, i.e., it is encoded by one gene, and, essentially, it is well tolerated by the patients. Numerous new implications of this cytokine have been proposed and tested in preclinical and clinical trials, including the combined application of GM-CSF and IL-2 as 
adjuvants in cutaneous melanoma along with autologous vaccine [10]. However, it is necessary to mention that the use of cytokines as adjuvants in vaccines is considered controversial because they can sometimes have serious side effects such as vascular leak syndrome [11]. An interesting idea is the production and application of "fusokines", hybrid molecules generated after cloning and fusing two separate cytokine encoding cDNAs into a single open reading frame, however these experiments have been limited to the murine experimental models [12].

Figure 1. The families of cytokines (according to the Kyoto Encyclopedia of Genes and Genomes [4]).

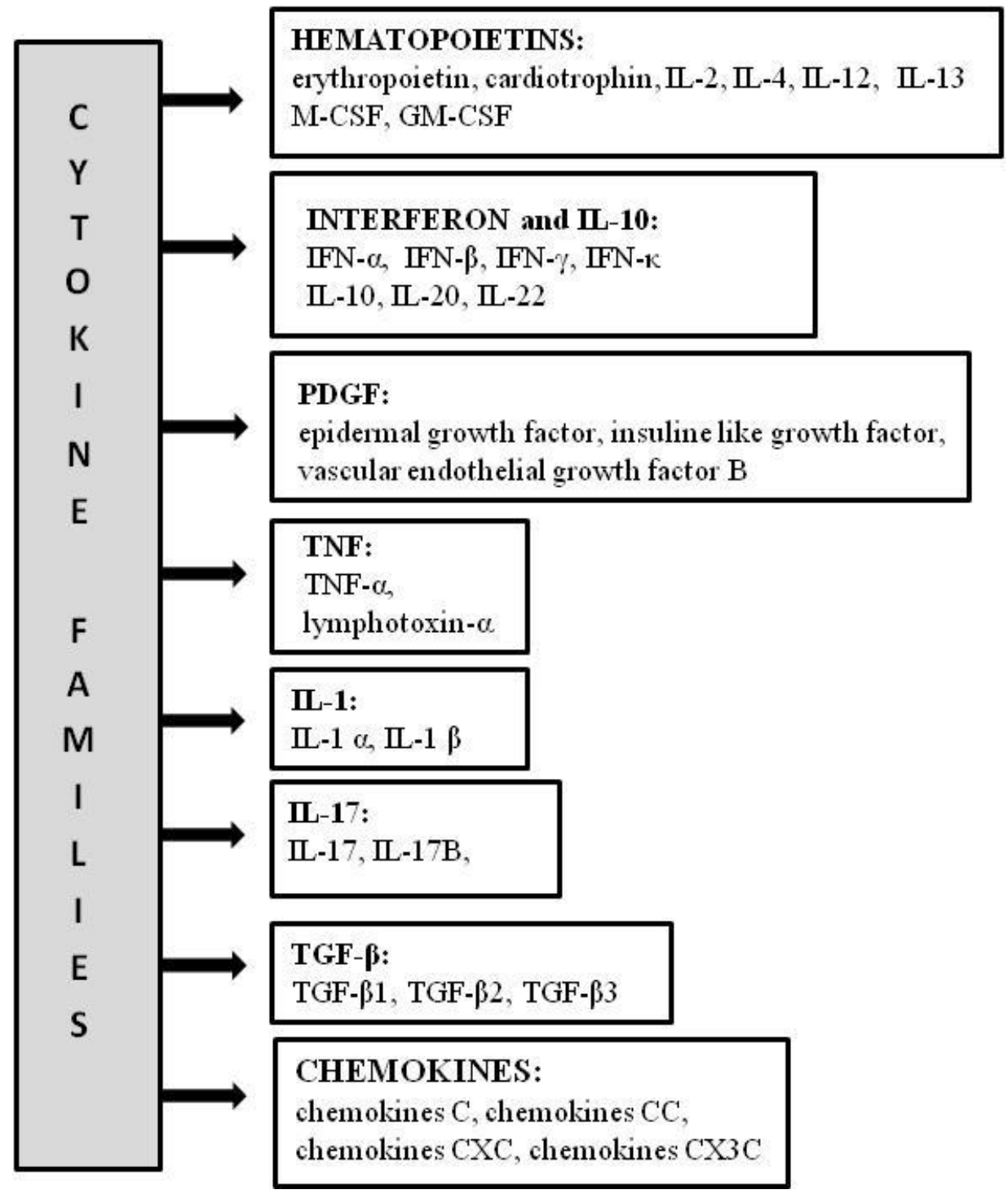

Table 1. Examples of cytokines approved for use in humans. Modified from $[7,8]$.

\begin{tabular}{lll}
\hline Cytokine & Disease or Indication & Drug Name (Company) \\
\hline G-CSF & Neutropenia & Neupogen/Filgrastim (Hoffmann-La Roche) \\
\hline \multirow{3}{*}{ GM-CSF } & Leukemia & \\
& Bone marrow & Leukine/Sargramostin (Bayer) \\
& Stem cell transplants & \\
\hline
\end{tabular}


Table 1. Cont.

\begin{tabular}{|c|c|c|}
\hline Cytokine & Disease or Indication & Drug Name (Company) \\
\hline Interferon- $\alpha($ INF- $\alpha)$ & $\begin{array}{l}\text { Chronic hepatitis B } \\
\text { Chronic hepatitis C } \\
\text { Hairy cell leukemia } \\
\text { Chronic myeloid leukemia } \\
\text { Condyloma acuminate } \\
\text { AIDS-related Kaposi's sarcoma } \\
\text { genital warts }\end{array}$ & $\begin{array}{l}\text { Intron A (Schering Plough) } \\
\text { Roferon A (Hoffman La Roche) } \\
\text { Infergen (Three Rivers Pharmaceuticals) } \\
\text { Alferon N (HEMISPHERx Biopharma) } \\
\text { Pegasys (Genentech USA/Roche) } \\
\text { Pegintron (Merck) }\end{array}$ \\
\hline Interferon- $\beta$ (INF- $\beta$ ) & Relapsing multiple sclerosis & $\begin{array}{l}\text { Betaseron (Bayer) } \\
\text { Avonex (Biogen Idec) }\end{array}$ \\
\hline Interferon- $\gamma(\mathrm{INF}-\gamma)$ & $\begin{array}{l}\text { Malignant osteopetrosis } \\
\text { Chronic granulomatous disease }\end{array}$ & Actimmune (Intermune Pharma) \\
\hline $\begin{array}{l}\text { Erythropoietin- } \alpha \\
(\text { EPO- } \alpha)\end{array}$ & $\begin{array}{l}\text { Anemia due to chronic renal failure } \\
\text { HIV infected patients } \\
\text { Chemotherapy } \\
\text { Primary bone marrow disorders }\end{array}$ & $\begin{array}{l}\text { Eprex (Cilag Jansen) } \\
\text { Epogen (Amgen) } \\
\text { Procrit (Ortho Biotech) }\end{array}$ \\
\hline IL-2 & $\begin{array}{l}\text { Metastatic renal cell cancer } \\
\text { Metastatic melanoma }\end{array}$ & $\begin{array}{l}\text { Aldesleukin (Novartis) } \\
\text { Proleukin (Prometheus Laboratories) }\end{array}$ \\
\hline IL-11 & Thrombocytopenia & $\begin{array}{l}\text { Oprelvekin/Neumega (Genetics Institute, Inc./ } \\
\text { Wyeth/Pfizer) }\end{array}$ \\
\hline
\end{tabular}

\section{Recombinant Cytokines from Plant-Based Platforms}

Plant-based production of recombinant cytokines is an emerging area and most previous research has concentrated on a few well-characterized cytokines. Some most interesting examples from the list shown in Table 2 are briefly discussed below.

\subsection{Hematopoietin Family}

Erythropoietin was one of the first cytokines produced in plant cells [13]. The cDNA encoding human erythropoietin was expressed from the $35 \mathrm{~S}$ promoter of cauliflower mosaic virus (CaMV) in the tobacco BY2 cells. The signal peptide at the $N$-terminus was intended to enable the extracellular secretion of the recombinant protein. The secretion was observed in the protoplasts cultures, while in the cell cultures erythropoietin was translocated though the cellular membrane but it stayed bound by the cell wall and was not secreted into the medium. Most probably, the size of $30 \mathrm{kDa}$ was too large for free migration through the cell wall. The protein is glycosylated in animal cells, so was examined in plant cells, however the pattern and length of the sugar chain were different. Unfortunately, only a low yield $(0.0026 \%$ of total soluble protein [TSP]) was achieved. The protein was biologically active in vitro but not in vivo. The possible explanation for this might be the difference in glycosylation, which is known to affect the protein stability in blood. 
Table 2. Examples of cytokines produced in plant-based systems. Different expression systems are marked differently (no background-suspension cultures; light grey-transgenic or transplastomic plants; dark grey-plant virus-based production); nos-nopaline transcriptional terminator, MUbi-1 i Scubi-9-polyubiquitin promoters; * Method of transformation: T-Agrobacterium-mediated; M-microbombardment, V-viral vector, L-lipofectin-mediated transformation of protoplasts. The examples concern human cytokines unless indicated otherwise.

\begin{tabular}{|c|c|c|c|c|}
\hline Cytokine & * Method/Plant Material & Selected Elements of the Expression Cassette & Expression Level/Yield & Reference \\
\hline erythropoietin & $\begin{array}{l}\text { T/tobacco (BY2) cells } \\
\text { suspension }\end{array}$ & $35 \mathrm{~S}$ promoter and terminator & $0.0026 \%$ TSP; 25 pg/L & {$[13]$} \\
\hline G-CSF & T/tobacco cells suspension & $\begin{array}{l}35 \mathrm{~S} \text { promoter with the double enhancer, } \Omega \text {-translation enhancer; } \\
\text { nos terminator }\end{array}$ & $105 \mu \mathrm{g} / \mathrm{L}$ & [14] \\
\hline GM-CSF & T/tobacco cells suspension & $\begin{array}{l}35 \mathrm{~S} \text { promoter, translation enhancer from TEV, His tag, } \\
\text { T7 terminator }\end{array}$ & $\begin{array}{l}150 \mu \mathrm{g} / \mathrm{L} \text { (intercellular); } 250 \mu \mathrm{g} / \mathrm{L} \\
\text { (secretory) }\end{array}$ & [15] \\
\hline GM-CSF & T/tobacco cells suspension & 35S promoter with the double enhancer, nos terminator & $180-780 \mu \mathrm{g} / \mathrm{L}$ & [16] \\
\hline GM-CSF & M/rice cells suspension & rice amylase promoter and signal peptide & $\begin{array}{l}129 \mathrm{mg} / \mathrm{L} \\
(25 \% \text { secreted proteins })\end{array}$ & [17] \\
\hline GM-CSF & $\mathrm{M} /$ rice cells suspension & $\begin{array}{l}\text { rice amylase promoter and signal peptide, RNAi-mediated } \\
\text { silencing of } \alpha \text {-amylase gene to } 8.2 \%\end{array}$ & $280 \mathrm{mg} / \mathrm{L}$ & [18] \\
\hline GM-CSF & $\mathrm{M} /$ rice cells suspension & $\begin{array}{l}\text { rice amylase promoter and signal peptide, RNAi-mediated } \\
\text { silencing of cysteine proteinase }\end{array}$ & $290 \mathrm{mg} / \mathrm{L}$ & [19] \\
\hline GM-CSF & $\mathrm{M} /$ rice cells suspension & $\begin{array}{l}\text { rice amylase promoter and signal peptide; co-expression } \\
\text { of gene encoding synthetic protease inhibitor (SPI-II) }\end{array}$ & $250 \mathrm{mg} / \mathrm{L}$ & [20] \\
\hline GM-CSF & M/sugarcane leaves & $M U b i-1$ promoter from maize or $S C u b i-9$ from sugarcane & $0.02 \% \mathrm{TSP}$ & [21] \\
\hline GM-CSF & T/tobacco seeds & $\begin{array}{l}\text { Gt1, Gt3 (glutelin) promoters and signal peptide, } \\
\text { nos terminator }\end{array}$ & $0.005-0.03 \%$ TSP & [22] \\
\hline GM-CSF & T/tobacco seeds & Gtl (glutelin) promoter and signal peptide, nos terminator & $1.3 \%$ TSP & [23] \\
\hline GM-CSF & T/rice seeds & $\begin{array}{l}\text { Gt13a (glutelin) promoter (specific for seed endosperm) and } \\
\text { glutelin signal peptide, nos terminator, codon optimalization }\end{array}$ & $0.5-14 \mu \mathrm{g} / \mathrm{seed}$ & [24] \\
\hline Murine GM-CSF & T/tobacco leaves & RbcS1 Promoter; signal peptide, KDEL & $19 \mu \mathrm{g} / \mathrm{g}$ fresh leaves; $0.22 \%$ & [25] \\
\hline
\end{tabular}


Table 2. Cont.

\begin{tabular}{|c|c|c|c|c|}
\hline Cytokine & * Method/Plant Material & Selected Elements of the Expression Cassette & Expression Level/Yield & Reference \\
\hline GM-CSF & V/N. benthamiana leaves & PVX-derived vector: $35 \mathrm{~S}$ promoter, His tag & $0.2-2 \%$ TSP & [26] \\
\hline IL-2 & T/tobacco cells suspension & $35 \mathrm{~S}$ promoter, $\mathrm{T} 7$ terminator & $0.09 \mathrm{mg} / \mathrm{L}$ & [27] \\
\hline IL-2 & $\mathrm{T} /$ potato tubers & patatin promoter; nos terminator & $115 \mathrm{U} / \mathrm{mg} \mathrm{TSP}$ & [28] \\
\hline Murine IL-2 & $\begin{array}{l}\text { T/Arabidopsis seeds } \\
\text { T/tobacco seeds }\end{array}$ & $\begin{array}{l}\text { novel binary Gateway vector (pPphasGW) containing } \\
\beta \text {-phaseolin promoter from common bean and the signal peptide } \\
\text { of the Arabidopsis } 2 \mathrm{~S} 2 \text { seed storage protein gene; KDEL }\end{array}$ & $\begin{array}{l}\text { Much higher yield in Arabidopsis } \\
\text { than in tobacco: } 0.3 \mathrm{mg} / \mathrm{g} \text { of seeds } \\
(0.7 \% \mathrm{TSP}) \text {; biologically active } \\
\text { in vitro }\end{array}$ & [29] \\
\hline IL-4 & T/tobacco leaves & $\begin{array}{l}\text { 35S promoter with double enhancer, t-CUP-translation } \\
\text { enhancer, ELP, KDEL, nos terminator }\end{array}$ & $0.086 \%$ TSP & [30] \\
\hline IL-4 & $\begin{array}{l}\text { T/tobacco leaves, } \\
\text { T/potato tubers }\end{array}$ & $35 \mathrm{~S}$ promoter, KDEL sequence & $\begin{array}{l}0.1 \% \text { TSP in tobacco; } \\
0.08 \% \text { TSP in potato }\end{array}$ & [31] \\
\hline IL-4 & T/tobacco cells suspension & 35S CaMV promoter, $\mathrm{T} 7$ terminator & $0.45 \mathrm{mg} / \mathrm{L}$ & [27] \\
\hline IL-10 & T/tobacco leaves & $\begin{array}{l}\text { 35S promoter with double enhancer, t-CUP-translation } \\
\text { enhancer, ELP, KDEL, nos terminator }\end{array}$ & $0.27 \%$ TSP & [30] \\
\hline IL-10 & T/tobacco leaves & $\begin{array}{l}\text { (A) promoter } 35 \mathrm{~S} \text { CaMV, with or without His tag, } \\
\text { chloroplast leader peptide } \\
\text { (B) promotor } 35 \mathrm{~S} \mathrm{CaMV} \text {, His tag; mitochondria } \\
\text { leader peptide }\end{array}$ & $\begin{array}{l}\text { (A) } 7 \mathrm{ng} / \mathrm{mg} \text { TSP (without His); } \\
43 \mathrm{ng} / \mathrm{mg} \mathrm{TSP} \text { (with His) } \\
\text { (B) no accumulation }\end{array}$ & [32] \\
\hline IL-10 & T/rice seeds & $\begin{array}{l}\text { GluB-1 promoter and signal peptide, His tag, KDEL, } \\
\text { codon optimization }\end{array}$ & $\begin{array}{l}2 \mathrm{mg} \text { of pure IL- } 10 \text { per } 40 \mathrm{~g} \\
\text { of rice powder }\end{array}$ & [33] \\
\hline IL-10 & T/tobacco leaves & $\begin{array}{l}\text { 35S promoter with double enhancer; three constructs for each } \\
\text { viral IL-10 or murine IL-10, ER-targeted, plasma membrane } \\
\text { (IL-10 facing the apoplast), ER-membrane (IL-10 facing the } \\
\text { cytosol) assayed in transient expression system, cassettes for } \\
\text { ER-targeted cytokines were used for the stable expression }\end{array}$ & $\begin{array}{l}\text { Viral: } 10.8 \mu \mathrm{g} / \mathrm{g} \text { fresh leaves } \\
\text { Murine: } 37.0 \mu \mathrm{g} / \mathrm{g} \text { fresh leaves }\end{array}$ & [34] \\
\hline IL-12 & T/tobacco leaves & $35 \mathrm{~S}$ promoter and terminator & $40 \mathrm{ng} / \mathrm{g}$ & [35] \\
\hline
\end{tabular}


Table 2. Cont

\begin{tabular}{|c|c|c|c|c|}
\hline Cytokine & * Method/Plant Material & Selected Elements of the Expression Cassette & Expression Level/Yield & Reference \\
\hline IL-12 & T/tomato leaves and fruits & $35 \mathrm{~S}$ promoter with double enhancer; $35 \mathrm{~S}$ terminator & $\begin{array}{l}7.3 \mu \mathrm{g} / \mathrm{g} \text { leaves } \\
4.3 \mu \mathrm{g} / \mathrm{g} \text { fruits }\end{array}$ & {$[36,37]$} \\
\hline IL-12 & T/tobacco cells suspension & $35 \mathrm{~S}$ promoter with double enhancer; $\Omega$-translation enhancer & $175 \mu \mathrm{g} / \mathrm{L}$ & [38] \\
\hline IL-13 & T/tobacco leaves & $\begin{array}{l}\text { double } 35 \mathrm{~S} \text { promoter; translation enhancer from AMV; KDEL; } \\
\text { nos terminator }\end{array}$ & $0.15 \%$ TSP & [39] \\
\hline IL-18 & T/tobacco leaves & $\begin{array}{l}\text { 35S promoter with double enhancer, } \Omega \text {-translation enhancer, } \\
\text { nos terminator }\end{array}$ & $0.004-0.051 \%$ TSP; $351 \mathrm{ng} / \mathrm{g}$ & [40] \\
\hline cardiotrophin-1 & $\begin{array}{l}\text { M/tobacco leaves, chloroplasts } \\
\text { transformation }\end{array}$ & $\begin{array}{l}\text { (A) promotor } r r n \text { (promoter 16S RNA), translation enhancer } \\
\text { (5'UTR/leader sequence of the phage T7 gene 10) } \\
\text { (B) } p s b A \text { promoter and translation enhancer (5'UTR } p s b A \text { ) }\end{array}$ & $\begin{array}{l}\text { (A) } 0.14 \mathrm{mg} / \mathrm{g} \text { leaves } \\
\text { (B) up to } 1.14 \mathrm{mg} / \mathrm{g} \text { leaves }\end{array}$ & [41] \\
\hline $\begin{array}{l}\text { IFN- } \alpha 2 b \\
\text { IFN- } \alpha 8\end{array}$ & T/potato & - & $560 \mathrm{IU} / \mathrm{g}$ of tissue & [42] \\
\hline IFN $\alpha$ & $\begin{array}{l}\text { L/tomato (leaf tissue and } \\
\text { cells suspension) }\end{array}$ & $\begin{array}{l}\mathrm{P} 1 \text { portion of the dual "bi-directional" promoter from } \\
\text { A. tumefaciens cDNA, polyadenylation signal from } \\
\text { A. tumefaciens gene-7 }\end{array}$ & 923-3029 U/g FW tissue & [43] \\
\hline IFN- $\alpha 2$ & $\begin{array}{l}\text { V/squash (Cucurbita pepo) and } \\
\text { cucumber (Cucumis sativus) }\end{array}$ & $\begin{array}{l}\text { Viral vector dirived from attenuated zucchini yellow mosaic } \\
\text { potyvirus (AG) }\end{array}$ & max. $430,000 \mathrm{IU} / \mathrm{FW}$ of leaves & {$[44]$} \\
\hline IFN- $\alpha 2 b$ & $\begin{array}{l}\text { M/tobacco leaves, chloroplasts } \\
\text { transformation }\end{array}$ & $\begin{array}{l}\text { Cassette: } 5 \text { 'UTR/HIS/THR/IFN } \alpha 2 \mathrm{~b} \text { cloned into the chloroplast } \\
\text { vector pLD-CtV }\end{array}$ & $3 \mathrm{mg} / \mathrm{g}, 20 \% \mathrm{TSP}$ & [45] \\
\hline IFN- $\alpha 2 b$ & T/carrot leaves & $\begin{array}{l}\text { (A) } 35 \mathrm{~S} \text { promoter, nos terminator, calreticulin apoplast } \\
\text { targeting signal } \\
\text { (B) taproot-specific Mll promoter, nos terminator, calreticulin } \\
\text { apoplast targeting signal }\end{array}$ & $\begin{array}{l}\text { Biological activity on average: } \\
\text { (A) } 26.8 \times 10^{3} \mathrm{U} / \mathrm{g} \text { FW of young } \\
\text { leaves } \\
\text { (B) } 8.56 \times 10^{3} \mathrm{U} / \mathrm{g} \mathrm{FW} \text { of roots }\end{array}$ & {$[46]$} \\
\hline IFN $\beta$ & $\begin{array}{l}\text { transient, agroinfiltration of the } \\
\text { leaves of lettuce }\end{array}$ & $35 \mathrm{~S}$ promoter, nos terminator & $3.1 \times 10^{4} \mathrm{IU} / \mathrm{mL}$ & [47] \\
\hline
\end{tabular}


Table 2. Cont.

\begin{tabular}{|c|c|c|c|c|}
\hline Cytokine & * Method/Plant Material & Selected Elements of the Expression Cassette & Expression Level/Yield & Reference \\
\hline IFN $\gamma$ & T/rice cells suspension & $\begin{array}{l}\text { (A) constitutive maize ubiquitin promoter, with or without } \\
\alpha \text { Amy3 leader peptide; His tag; } \\
\text { (B) sucrose-starvation inducible promoter (rice } \alpha \text { Amy } 3 \\
\text { promoter); with or without } \alpha \text { Amy3 leader peptide; His tag }\end{array}$ & $\begin{array}{l}\text { (A) } 11.1 \mathrm{ng} / \mathrm{mL} \text { (secretory) and } \\
699.79 \mathrm{ng} / \mathrm{g} \text { cell (intracellular) } \\
\text { (B) } 17.4 \mathrm{ng} / \mathrm{mL} \text { media (secretory) } \\
\text { and } 131.6 \mathrm{ng} / \mathrm{g} \text { cell (intracellular) }\end{array}$ & [48] \\
\hline Chicken IFN- $\alpha$ & $\begin{array}{l}\text { Transient expression, } \\
\text { agroinfiltration of the } \\
\text { leaves of lettuce }\end{array}$ & $35 \mathrm{~S}$ promoter, nos terminator & $0.393 \mu \mathrm{g} / \mathrm{kg}$ tissue, $0.0004 \% \mathrm{TSP}$ & [49] \\
\hline Fish IFN- $\alpha 1$ & $\begin{array}{l}\text { T/rice } \\
\text { T/potato }\end{array}$ & $35 \mathrm{~S}$ promoter with double enhancer, nos terminator & $\begin{array}{l}\text { Biological activity: } \\
\text { in rice-up to } 0.82 \mathrm{U} / \mathrm{mg} \text { leaves; } \\
\text { in potato-up to } 5.4 \mathrm{U} / \mathrm{mg} \text { leaves }\end{array}$ & [50] \\
\hline TNF- $\alpha$ & T/potato & $35 \mathrm{~S}$ promoter, $\Omega$-translation enhancer, SEKDEL sequence & $15 \mu \mathrm{g} / \mathrm{g}$ tissue & [51] \\
\hline $\begin{array}{l}\text { Fibroblast growth } \\
\text { factor } 8 \text { isoform b } \\
\text { (FGF8b) }\end{array}$ & T/tobacco leaves & $\begin{array}{l}\text { 35S promoter with double enhancer; } 35 \text { S terminator ,c-myc, } \\
\text { His, KDEL }\end{array}$ & $4.1 \% \mathrm{TSP}$ & [52] \\
\hline $\begin{array}{l}\text { Insulin like growth } \\
\text { factor } 1(\mathrm{IGF}-1)\end{array}$ & $\mathrm{M} /$ tobacco, transplastomic & $\begin{array}{l}\text { psbA promoter, translantion enhancer ( } 5^{\prime} \mathrm{UTR} \text { psbA) } \\
\text { and ZZ-tag from S. aureus, codon optimization }\end{array}$ & up to $32 \%$ TSP & [53] \\
\hline $\begin{array}{l}\text { Insulin like growth } \\
\text { factor } 1 \text { (IGF-1) }\end{array}$ & M/rice seeds & $\begin{array}{l}\text { Glutelin }(G t 13 a) \text { promoter, the } G t 13 a \text { signal peptide in } \\
\text { frame with the fusion protein containing IGF- } 1 \text { attached } \\
\text { to the } C \text {-terminus of ER luminal binding protein (BipC), } \\
\text { nos terminator }\end{array}$ & $\begin{array}{l}\text { up to } 6.8 \% \text { of total seed protein; } \\
\text { biologically active in vivo } \\
\text { (effectively reduced blood glucose } \\
\text { in diabetic mice) }\end{array}$ & [54] \\
\hline
\end{tabular}


Several independent groups focus on the production of human GM-CSF. Initially, it was produced in tobacco $[15,16]$ and rice [17-20] cell suspension cultures. One of the most interesting approaches to improve the yield was the addition of either mineral salts or BSA to the growth medium, which stabilized the secreted cytokine [15]. A significant (up to 4-fold) increase of the yield was achieved due to the addition of $5 \%(\mathrm{w} / \mathrm{v})$ gelatin to the medium [16]. However, in cultures older than 4 days, gelatin inhibited cell growth, presumably by activation of proteolytic enzymes. Much higher efficiency was achieved in cultures of rice cell suspension, particularly with the specific promoter of rice amylase, Ramy3D [17]. Using this system, a yield of $129 \mathrm{mg} / \mathrm{L}$ of culture was achieved in the absence of sugar (when this promoter is activated). The system was subsequently optimized in three strategies: (i) silencing of the gene encoding a-amylase, a dominant protein secreted by rice cells [18]; (ii) silencing of the gene encoding cysteine proteinase secreted by the rice cells to the medium [19]; and (iii) co-expression of cytokine with the protease inhibitor [20]. Each of these strategies increased the yield of recombinant GM-CSF at least two-fold.

Whole plant platforms were also used for GM-CSF production. The maximal yield in the leaves of transgenic sugarcane was about $0.02 \%$ [21] and in tobacco leaves about $0.22 \%$ of TSP [25]. In the seeds of transgenic rice recombinant GM-CSF accumulated up to $1.3 \%$ of TSP [23]. The highest expression (up to $2 \%$ TSP) was reported for the viral vector based on PVX (potato virus X) with modified coat protein [26]. In most cases the biological activity of recombinant GM-CSF was confirmed in vitro, while in at least in one case it was also verified in vivo in a mouse model [24].

The first report about the expression of recombinant IL-2 and IL-4 in tobacco cell suspension cultures was published in 1998 [27]. The authors assumed that the presence of intrinsic signal peptide would provide an efficient extracellular secretion of recombinant proteins. In fact, most of the cytokine produced was retained in the cells and only the secreted proteins had biological activity. Other strategies include targeting of the recombinant IL-4 proteins into endoplasmic reticulum, using the promoter specific to potato tubers or expression as a protein fusion with elastin, however the reported yield was never higher than $0.08 \%$ for IL-4 [30] or $115 \mathrm{U} / \mathrm{g}$ of potato tuber for IL-2 [28].

Other examples of cytokines from this group produced in plant-based platforms include cardiotrophin 1 [41], interleukin 12 [35-38], interleukin 13 [39] and interleukin 18 [40]. Interestingly, IL-12 was produced as a multimeric protein at levels exceeding 5\% of TSP after coinfiltration of Nicotiana benthamiana leaves with two Agrobacterium strains individually encoding each subunit [55]. Cardiotrophin 1 was produced in transplastomic tobacco plants with an efficiency of about 5\%. In addition, it appeared that its biological activity is inhibited by light, which most probably destroys the protein conformation [41].

\subsection{Interferon and IL-10 Family}

Interferons have been frequently selected as candidates for production in plant-based systems. The first reports about the plan-based production of human interferon date back to the beginning of the $90 \mathrm{~s}$ [56], however it was the usage of transplanstomic plants that allowed for the huge increase of yield, up to $20 \%$ of TSP [45]. It is worth mentioning that not only human interferons but also interferons from chicken [49] and salmon [50] were successfully produced in plant-based systems. 
In plant-based systems, interleukin 10 was targeted either to chloroplasts or mitochondria, with better results for the former organelle [32]. In the case of this cytokine, the best yield of $0.27 \%$ TSP was achieved after expression of IL-10 in fusion with elastin [30].

\subsection{Other Families}

The single representatives of the other families of cytokine were produced in plant systems (Table 2).

Tumor necrosis factor (TNF- $\alpha$ ), which is a member of the TNF family, has been produced in potatoes [51]. The authors used two types of expression cassettes, both containing 35S promoter of CaMV and the translation enhancer from TMV. One of the cassettes had additional sequences encoding the $N$-terminal signal peptide and the $C$-terminal SEQDEL peptide, responsible for ER targeting. However, this strategy did not result in any significant increase of cytokine accumulation. In both cases the yield was similar and reached about $15 \mu \mathrm{g}$ of biologically active TNF- $\alpha$ per $1 \mathrm{~g}$ of plant tissue.

Interleukin 18 belongs to the IL-1 family. In this case, the enhanced $35 \mathrm{~S}$ promoter and the translation enhancer from TMV were used; however the yield was moderate, up to $0.05 \%$ of TSP [40].

Bioactive human fibroblast growth factor $8 \mathrm{~b}$ (FGF), a member of PDGF family, was produced in tobacco plants [52]. The cDNA coding hFGF8b was cloned under control of the double CaMV 35S promoter (CaMV35SS). In an Agrobacterium-mediated transient expression system after vacuum leaves infiltration the yield of the Ni-NTA affinity chromatography purified proteins c-myc-His tagged FGF8b and His-KDEL tagged FGF8b was $2.7 \%$ and $4.1 \%$ of TSP (90 and $150 \mu \mathrm{g} / \mathrm{g} \mathrm{FW}$ ), respectively.

Another member of the same PDGF family, Insulin-like Growth Factor 1 (IGF-1), was efficiently produced in transplastomic plants [53]. Cell proliferation assays in human HU-3 cells demonstrated the biological activity of this recombinant protein.

\section{Prospects for Commercialization Plant-Produced Cytokines}

The successful introduction of plant-produced recombinant cytokines into the market might encounter problems similar to those encountered in the commercialization of any other PMPs [57]. These problems can be divided into two main categories: (i) technological (such as low yield, poor performance of the recombinant product or problems with postharvest bioprocessing) making the platforms economically uncompetitive and (ii) legal (such as public objections and stringent regulatory requirements for open-field cultivation of transgenic plants, high regulatory-approval costs and long timelines), which result in a long timeframe-to-market and a lack of interest from the potential investors.

\subsection{Strategies Used to Improve the Performance of Plant-Base Production Platforms}

The researchers dealing with molecular farming issues have always been aware of the needs for technological improvement. Various factors limit the yield of PMPs and there are multiple possibilities to overcome the yield and economic constrains. These problems have been frequently considered in many excellent reviews [58-60]. The concerns generally expressed with regard to PMPs also pertain to the plant-produced cytokines. Therefore, we would like to mention briefly only a few strategies, which 
were successfully applied in the case of this type of therapeutics. First of all, some PMPs can be produced in edible crops to eliminate the need for purification of the desired products in the case of oral application of the recombinant proteins. In addition, several critical elements must be optimized to get a high yield of PMP, including the use of tissue specific promoter or optimization of the codons within the transgene to match the optimal codons of the host. For example, efficient accumulation Insulin-like Growth Factor I (IGF) was achieved in transgenic tobacco chloroplasts after codon optimization of the transgene [34,53]. The native IGF gene (IGF-n) with less than optimal for chloroplast AT content of $41 \%$ or synthetic (IGF-s) gene with optimized $60 \%$ AT were cloned into a vector containing the $p s b A$ promoter, 5'UTR (which enhances translation under illumination) and 3'UTR (which increases the stability of the transcript). The IGF-n transgenic plants had an expression level of $9.5 \%$ TSP. In IGF-s plants, expression level increased to $11.3 \%$ TSP, however the expression of IGF was increased up to $32 \%$ TSP under continuous illumination by the chloroplast light regulatory elements. The importance of protein stability is illustrated by other reported cases, where significant elevation of the yield was achieved by targeting the PMP into the storage organs such as seeds or grains [22-24,33]. For example, a strong endosperm-specific promoter (Gt13a) and rice-preferred codons optimization improved the transcription and translation of hGM-CSF, giving the yield of $14 \mu \mathrm{g} / \mathrm{seed} \mathrm{[24].} \mathrm{In} \mathrm{this} \mathrm{case} \mathrm{also} \mathrm{a} \mathrm{signal} \mathrm{peptide} \mathrm{that} \mathrm{targeted} \mathrm{recombinant} \mathrm{protein} \mathrm{into} \mathrm{the}$ endomembrane system of rice endosperm such as the ER and protein bodies was used to protect against degradation by proteases. Additionally, it is worth mentioning that accumulation in seeds might eliminate the need for low temperature maintenance during transport and long-term storage of PMPs. There are also successful examples of fusion strategies being used to obtain the high yield of recombinant cytokines in plants, including IGF-1 produced in fusion with the $C$-terminus of a rice luminal binding protein [54]. The appropriately designed fusion, which does not interfere with the biological activity of the recombinant proteins, might be a safe and effective oral delivery system for cytokins in general.

Proteomic analysis of the effects of massive over-accumulation of GM-CSF in plants gave us some information about the fate of recombinant proteins in plant cells [61]. This work also indicated that the presence of recombinant protein might affect the total proteome of grain cells. For example, the major endogenous storage proteins, glutelin, globulin and prolamin, and a majority of carbohydrate-related proteins were down-regulated, while $26 \mathrm{~S}$ proteasome-related proteins and molecular chaperons were up-regulated in transgenic rice endosperm. The author concluded that over expression of recombinant proteins induced unfolded protein response and that overall protein trafficking in rice endosperm was affected. This work shows that the influence of transgene expression on host metabolism is an important issue.

\subsection{Other Problems to Consider}

The initial pictures describing the feasibility of the production of edible plant-made pharmaceuticals or vaccines in carrots or bananas appeared somewhat naive. A direct consumption (oral application) of plant parts containing recombinant therapeutics might be controversial because of the need to meet the existing rigorous regulations concerning consistent composition of medicines for humans. Most legal and regulatory issues linked to the commercialization of PMPs were extensively discussed in a number 
of recent reviews $[57,62,63]$ and they will not be repeated here. There are also other problems and questions regarding the use of genetically modified plants and their effects on the human health and the environment in general. These issues include some concerns regarding ethics, related to the risk of transferring transgene (especially antibiotic-resistance markers) from genetically modified plants to the environment, gut microflora and pathogenic microbes. As mentioned earlier, the risk of uncontrolled spreading of the transgene can be substantially reduced by the strategy of biocontainment or physical containment. In addition, using marker-free technology eliminates the risk of transfer of the marker genes $[64,65]$. There are also some religious issues related to the consumption of transgenic plants with animal genes introduced into them, especially, for some strict vegetarian people and some ethnical groups with certain food preferences and restrictions, but this concern is outside the scope of the present review.

It is necessary to mention that the avoidance of plant cultivation in open areas, applying various approaches of containment use and the usage of only isolated (purified) recombinant products lead, of course, to more expensive products and limit the direct use of GM plants as edible sources of recombinant therapeutics.

\section{Conclusions}

Recent development of knowledge about the immune system opens new perspectives for the application of cytokines and opens a potentially large market, however finding the niche for plant-produced recombinant cytokines in the pharmaceutical market might be tough. Many technical and regulatory challenges limit the availability of this sector for the prospective investors. All molecular farming projects, including those involved in the production of therapeutics for the treatment of immune system disorders, must consider the costs and feasibility of standardization, validation and licensing of the potential medical products. The biopharming industry is in a dynamic state and many companies involved in plant-based biomanufacturing of recombinant proteins cease to exist before the commercialization of any products [57]. Nevertheless, there are now about 20 PMPs, including at least one cytokine (interferon $\alpha$ ) in development as potential products for the pharmaceutical market [66].

\section{Acknowledgements}

This work was supported by the Ministry of Science and Higher Education of Poland (grant N302 061934). The collaboration was in part supported by the bilateral Czech-Polish joined research project "Evaluation of suitability of various plant-based platforms for the production of target compounds" and by COST Action FA0804: "Molecular farming: Plants as a production platform for high value proteins".

\section{References}

1. Barta, A.; Sommergruber, K.; Thompson, D.; Hartmuth, K.; Matzke, M.A.; Matzke, A.J.M. The expression of a nopaline synthase-human growth hormone chimaeric gene in transformed tobacco and sunflower callus tissue. Plant Mol. Biol. 1986, 6, 347-357. 
2. Sijmons, P.C.; Dekker, B.M.; Schrammeijer, B.; Verwoerd, T.C.; van den Elzen, P.J.; Hoekema, A. Production of correctly processed human serum albumin in transgenic plants. Nat. Biotechnol. 1990, 8, 217-221.

3. Obembe, O.O.; Popoola, J.O.; Leelavathi, S.; Reddy, S.V. Advances in plant molecular farming. Biotechnol. Adv. 2011, 29, 210-222.

4. Homepage of KEGG: Koto Encyclopedia of Genes and Genomes. Available online: http://www.genome.jp/kegg/ (accessed on 19 May 2011).

5. Homepage of Cytokines \& Cells Online Pathfinder Encyclopedia. Available online: http://www.copewithcytokines.org/cope.cgi (accessed on 19 May 2011).

6. Andersson, U.; Tracey, K.J. Molecular basis of applied biological therapeutics. J. Intern. Med. 2011, 269, 2-7.

7. Cutler, A.; Brombacher, F. Cytokine therapy. Ann. N. Y. Acad. Sci. 2005, 1056, 16-29.

8. Tayal, V.; Kalra, B.S. Cytokines and anti-cytokines as therapeutics-an update. Eur. J. Pharmacol. 2008, 579, 1-12.

9. Toka, F.N.; Pack, C.D.; Rouse, B.T. Molecular adjuvants for mucosal immunity. Immunol. Rev. 2004, 199, 100-112.

10. Elias, E.G.; Zapas, J.L.; McCarron, E.C.; Beam, S.L.; Hasskamp, J.H.; Culpepper, W.J. Sequential administration of GM-CSF (Sargramostim) and IL-2 +/- autologous vaccine as adjuvant therapy in cutaneous melanoma: An interim report of a phase II clinical trial. Cancer Biother. Radiopharm. 2008, 23, 285-291.

11. Batista-Duharte, A.; Lindblad, E.B.; Oviedo-Orta, E. Progress in understanding adjuvant immunotoxicity mechanisms. Toxicol. Lett. 2011, 203, 97-105.

12. Williams, P.; Galipeau, J. GMCSF-Interleukin fusion cytokines induce novel immune effectors that can serve as biopharmaceuticals for treatment of autoimmunity and cancer. J. Intern. Med. 2011, 269, 74-84.

13. Matsumoto, S.; Ikura, K.; Ueda, M.; Sasaki, R. Characterization of a human glycoprotein (erythropoietin) produced in cultured tobacco cells. Plant Mol. Biol. 1995, 27, 1163-1172.

14. Hong, S.-Y.; Kwon, T.-H.; Lee, J.-H.; Jang, Y.-S.; Yang, M.-S. Production of biologically active hG-CSF by transgenic plant cell suspension culture. Enzyme Microb. Technol. 2002, 30, 762-767.

15. James, E.A.; Wang, C.; Wang, Z.; Reeves, R.; Shin, J.H.; Magnuson, N.S.; Lee, J.M. Production and characterization of biologically active human GM-CSF secreted by genetically modified plant cells. Protein Expr. Purif. 2000, 19, 131-138.

16. Lee, J.H.; Kim, N.S.; Kwon, T.H.; Jang, Y.S.; Yang, M.S. Increased production of human granulocyte-macrophage colony stimulating factor (hGM-CSF) by the addition of stabilizing polymer in plant suspension cultures. J. Biotechnol. 2002, 96, 205-211.

17. Shin, Y.J.; Hong, S.Y.; Kwon, T.H.; Jang, Y.S.; Yang, M.S. High level of expression of recombinant human granulocyte-macrophage colony stimulating factor in transgenic rice cell suspension culture. Biotechnol. Bioeng. 2003, 82, 778-783.

18. Kim, N.S.; Kim, T.G.; Jang, Y.S.; Shin, Y.J.; Kwon, T.H.; Yang, M.S. Amylase gene silencing by RNA interference improves recombinant hGM-CSF production in rice suspension culture. Plant Mol. Biol. 2008, 68, 369-377. 
19. Kim, N.S.; Kim, T.G.; Kim, O.H.; Ko, E.M.; Jang, Y.S.; Jung, E.S.; Kwon, T.H.; Yang, M.S. Improvement of recombinant hGM-CSF production by suppression of cysteine proteinase gene expression using RNA interference in a transgenic rice culture. Plant Mol. Biol. 2008, 68, 263-275.

20. Kim, T.G.; Lee, H.J.; Jang, Y.S.; Shin, Y.J.; Kwon, T.H.; Yang, M.S. Co-expression of proteinase inhibitor enhances recombinant human granulocyte-macrophage colony stimulating factor production in transgenic rice cell suspension culture. Protein Expr. Purif. 2008, 61, 117-121.

21. Wang, M.L.; Goldstein, C.; Su, W.; Moore, P.H.; Albert, H.H. Production of biologically active GM-CSF in sugarcane: A secure biofactory. Transgenic Res. 2005, 14, 167-178.

22. Sardana, R.K.; Alli, Z.; Dudani, A.; Tackaberry, E.; Panahi, M.; Narayanan, M.; Ganz, P.; Altosaar, I. Biological activity of human granulocyte-macrophage colony stimulating factor is maintained in a fusion with seed glutelin peptide. Transgenic Res. 2002, 11, 521-531.

23. Sardana, R.; Dudani, A.K.; Tackaberry, E.; Alli, Z.; Porter, S.; Rowlandson, K.; Ganz, P.; Altosaar, I. Biologically active human GM-CSF produced in the seeds of transgenic rice plants. Transgenic Res. 2007, 16, 713-721.

24. Ning, T.; Xie, T.; Qiu, Q.; Yang, W.; Zhou, S.; Zhou, L.; Zheng, C.; Zhu, Y.; Yang, D. Oral administration of recombinant human granulocyte-macrophage colony stimulating factor expressed in rice endosperm can increase leukocytes in mice. Biotechnol. Lett. 2008, 30, 1679-1686.

25. Gora-Sochacka, A.; Redkiewicz, P.; Napiorkowska, B.; Gaganidze, D.; Brodzik, R.; Sirko, A. Recombinant mouse granulocyte-macrophage colony-stimulating factor is glycosylated in transgenic tobacco and maintains its biological activity. J. Interferon Cytokine Res. 2010, 30, $135-142$.

26. Zhou, F.; Wang, M.L.; Albert, H.H.; Moore, P.H.; Zhu, Y.J. Efficient transient expression of human GM-CSF protein in Nicotiana benthamiana using potato virus X vector. Appl. Microbiol. Biotechnol. 2006, 72, 756-762.

27. Magnuson, N.S.; Linzmaier, P.M.; Reeves, R.; An, G.; HayGlass, K.; Lee, J.M. Secretion of biologically active human interleukin-2 and interleukin-4 from genetically modified tobacco cells in suspension culture. Protein Expr. Purif. 1998, 13, 45-52.

28. Park, Y.; Cheong, H. Expression and production of recombinant human interleukin-2 in potato plants. Protein Expr. Purif. 2002, 25, 160-165.

29. Morandini, F.; Avesani, L.; Bortesi, L.; van Droogenbroeck, B.; de Wilde, K.; Arcalis, E.; Bazzoni, F.; Santi, L.; Brozzetti, A.; Falorni, A.; et al. Non-food/feed seeds as biofactories for the high-yield production of recombinant pharmaceuticals. Plant Biotechnol. J. 2011, doi: 10.1111/j.1467-7652.2011.00605.x.

30. Patel, J.; Zhu, H.; Menassa, R.; Gyenis, L.; Richman, A.; Brandle, J. Elastin-like polypeptide fusions enhance the accumulation of recombinant proteins in tobacco leaves. Transgenic Res. 2007, 16, 239-249.

31. Ma, S.; Huang, Y.; Davis, A.; Yin, Z.; Mi, Q.; Menassa, R.; Brandle, J.E.; Jevnikar, A.M. Production of biologically active human interleukin-4 in transgenic tobacco and potato. Plant Biotechnol. J. 2005, 3, 309-318.

32. Menassa, R.; Kennette, W.; Nguyen, V.; Rymerson, R.; Jevnikar, A.; Brandle, J. Subcellular targeting of human interleukin-10 in plants. J. Biotechnol. 2004, 108, 179-183. 
33. Fujiwara, Y.; Aiki, Y.; Yang, L.; Takaiwa, F.; Kosaka, A.; Tsuji, N.M.; Shiraki, K.; Sekikawa, K. Extraction and purification of human interleukin-10 from transgenic rice seeds. Protein Expr. Purif. 2010, 72, 125-130.

34. Bortesi, L.; Rossato, M.; Schuster, F.; Raven, N.; Stadlmann, J.; Avesani, L.; Falorni, A.; Bazzoni, F.; Bock, R.; Schillberg, S.; et al. Viral and murine interleukin-10 are correctly processed and retain their biological activity when produced in tobacco. BMC Biotechnol. 2009, 9, 22.

35. Gutierrez-Ortega, A.; Avila-Moreno, F.; Saucedo-Arias, L.J.; Sanchez-Torres, C.; Gomez-Lim, M.A. Expression of a single-chain human interleukin-12 gene in transgenic tobacco plants and functional studies. Biotechnol. Bioeng. 2004, 85, 734-740.

36. Gutierrez-Ortega, A.; Sandoval-Montes, C.; de Olivera-Flores, T.J.; Santos-Argumedo, L.; Gomez-Lim, M.A. Expression of functional interleukin-12 from mouse in transgenic tomato plants. Transgenic Res. 2005, 14, 877-885.

37. Sanchez-Hernandez, C.; Gutierrez-Ortega, A.; Aguilar-Leon, D.; Hernandez-Pando, R.; Gomez-Lim, M.; Gomez-Garcia, B. In vivo activity of plant-based interleukin-12 in the lung of Balb/c mouse. BMC Res. Notes 2010, 3, 151.

38. Kwon, T.H.; Seo, J.E.; Kim, J.; Lee, J.H.; Jang, Y.S.; Yang, M.S. Expression and secretion of the heterodimeric protein interleukin-12 in plant cell suspension culture. Biotechnol. Bioeng. 2003, $81,870-875$.

39. Wang, D.J.; Brandsma, M.; Yin, Z.; Wang, A.; Jevnikar, A.M.; Ma, S. A novel platform for biologically active recombinant human interleukin-13 production. Plant Biotechnol. J. 2008, 6, 504-515.

40. Zhang, B.; Yang, Y.H.; Lin, Y.M.; Rao, Q.; Zheng, G.G.; Wu, K.F. Expression and production of bioactive human interleukin-18 in transgenic tobacco plants. Biotechnol. Lett. 2003, 25, 1629-1635.

41. Farran, I.; Rio-Manterola, F.; Iniguez, M.; Garate, S.; Prieto, J.; Mingo-Castel, A.M. High-density seedling expression system for the production of bioactive human cardiotrophin-1, a potential therapeutic cytokine, in transgenic tobacco chloroplasts. Plant Biotechnol. J. 2008, 6, 516-527.

42. Ohya, K.; Matsumura, T.; Ohashi, K.; Onuma, M.; Sugimoto, C. Expression of two subtypes of human IFN-alpha in transgenic potato plants. J. Interferon Cytokine Res. 2001, 21, 595-602.

43. Sawahel, W.A. The production of transgenic potato plants expressing human alpha-interferon using lipofectin-mediated transformation. Cell. Mol. Biol. Lett. 2002, 7, 19-29.

44. Arazi, T.; Slutsky, S.G.; Shiboleth, Y.M.; Wang, Y.; Rubinstein, M.; Barak, S.; Yang, J.; Gal-On, A. Engineering zucchini yellow mosaic potyvirus as a non-pathogenic vector for expression of heterologous proteins in cucurbits. J. Biotechnol. 2001, 87, 67-82.

45. Arlen, P.A.; Falconer, R.; Cherukumilli, S.; Cole, A.; Cole, A.M.; Oishi, K.K.; Daniell, H. Field production and functional evaluation of chloroplast-derived interferon-alpha2b. Plant Biotechnol. J. 2007, 5, 511-525.

46. Luchakivskaya, Y.; Kishchenko, O.; Gerasymenko, I.; Olevinskaya, Z.; Simonenko, Y.; Spivak, M.; Kuchuk, M. High-level expression of human interferon alpha-2b in transgenic carrot (Daucus carota L.) plants. Plant Cell Rep. 2011, 30, 407-415.

47. Li, J.; Chen, M.; Liu, X.-W.; Zhang, H.-C.; Shen, F.F.; Wang, G.P. Transient expression of an active human interferon-beta in lettuce. Sci. Hortic. 2007, 112, 258-265. 
48. Chen, T.L.; Lin, Y.L.; Lee, Y.L.; Yang, N.S.; Chan, M.T. Expression of bioactive human interferon-gamma in transgenic rice cell suspension cultures. Transgenic Res. 2004, 13, 499-510.

49. Song, L.; Zhao, D.G.; Wu, Y.J.; Li, Y. Transient expression of chicken alpha interferon gene in lettuce. J. Zhejiang Univ. Sci. B 2008, 9, 351-355.

50. Fukuzawa, N.; Tabayashi, N.; Okinaka, Y.; Furusawa, R.; Furuta, K.; Kagaya, U.; Matsumura, T. Production of biologically active Atlantic salmon interferon in transgenic potato and rice plants. J. Biosci. Bioeng. 2010, 110, 201-207.

51. Ohya, K.; Itchoda, N.; Ohashi, K.; Onuma, M.; Sugimoto, C.; Matsumura, T. Expression of biologically active human tumor necrosis factor-alpha in transgenic potato plant. J. Interferon Cytokine Res. 2002, 22, 371-378.

52. Potula, H.H.; Kathuria, S.R.; Ghosh, A.K.; Maiti, T.K.; Dey, S. Transient expression, purification and characterization of bioactive human fibroblast growth factor $8 \mathrm{~b}$ in tobacco plants. Transgenic Res. 2008, 17, 19-32.

53. Daniell, H.; Ruiz, G.; Denes, B.; Sandberg, L.; Langridge, W. Optimization of codon composition and regulatory elements for expression of human insulin like growth factor-1 in transgenic chloroplasts and evaluation of structural identity and function. BMC Biotechnol. 2009, 9, 33.

54. Xie, T.; Qiu, Q.; Zhang, W.; Ning, T.; Yang, W.; Zheng, C.; Wang, C.; Zhu, Y.; Yang, D. A biologically active rhIGF-1 fusion accumulated in transgenic rice seeds can reduce blood glucose in diabetic mice via oral delivery. Peptides 2008, 29, 1862-1870.

55. Medrano, J.; Reidy, M.J.; Liu, J.; Ayala, M.; Dolan, M.C.; Cramer, C.L. Rapid system for evaluating bioproduction capacity of complex pharmaceutical proteins in plants. In Methods in Molecular Biology, Recombinant Proteins from Plants; Faye, L., Gomord, V., Eds.; Humana Press: New York, NY, USA, 2009; Volume 483, pp. 41-67.

56. Edelbaum, O.; Stein, D.; Holland, N.; Gafni, Y.; Livneh, O.; Novick, D.; Rubinstein, M.; Sela, I. Expression of active human interferon-beta in transgenic plants. J. Interferon Res. 1992, 12, 449-453.

57. Davies, H.M. Review article: Commercialization of whole-plant systems for biomanufacturing of protein products: Evolution and prospects. Plant Biotechnol. J. 2010, 8, 845-861.

58. Ramessar, K.; Capell, T.; Christou, P. Molecular pharming in cereal crops. Phytochem. Rev. 2008, 7, 579-592.

59. Schillberg, S.; Twyman, R.M.; Fischer, R. Opportunities for recombinant antigen and antibody expression in transgenic plants-technology assessment. Vaccine 2005, 23, 1764-1769.

60. Sharma, A.K.; Sharma, M.K. Plants as bioreactors: Recent developments and emerging opportunities. Biotechnol. Adv. 2009, 27, 811-832.

61. Luo, J.; Ning, T.; Sun, Y.; Zhu, J.; Zhu, Y.; Lin, Q.; Yang, D. Proteomic analysis of rice endosperm cells in response to expression of hGM-CSF. J. Proteome Res. 2009, 8, 829-837.

62. Sparrow, P.A.; Irwin, J.A.; Dale, P.J.; Twyman, R.M.; Ma, J.K. Pharma-Planta: Road testing the developing regulatory guidelines for plant-made pharmaceuticals. Transgenic Res. 2007, 16, 147-161.

63. Spok, A.; Twyman, R.M.; Fischer, R.; Ma, J.K.; Sparrow, P.A. Evolution of a regulatory framework for pharmaceuticals derived from genetically modified plants. Trends Biotechnol. 2008, 26, 506-517. 
64. Lutz, K.A.; Maliga, P. Construction of marker-free transplastomic plants. Curr. Opin. Biotechnol. 2007, 18, 107-114.

65. Barampuram, S.; Zhang, Z.J. Recent advances in plant transformation. Methods Mol. Biol. 2011, 701, 1-35.

66. Paul, M.; Ma, J.K. Plant-made pharmaceuticals: Leading products and production platforms. Biotechnol. Appl. Biochem. 2011, 58, 58-67.

(C) 2011 by the authors; licensee MDPI, Basel, Switzerland. This article is an open access article distributed under the terms and conditions of the Creative Commons Attribution license (http://creativecommons.org/licenses/by/3.0/). 